\title{
Social justice and the judicial interpretation of international equal protection law
}

\author{
Tilmann Altwicker* \\ University of Zurich, Seilergraben 49, CH-8001 Zurich/Switzerland \\ Email: tilmann.altwicker@rwi.uzh.ch
}

\begin{abstract}
Social justice is turning into an international concern. This development is a response to the continuous rise of socioeconomic inequality - the gap between the rich and the poor -growing in several OECD member states since the 1970s. International human rights law (IHRL) presently only establishes a weak normative framework regarding social justice. This article argues that the full potential of this framework has still not been activated by international human rights adjudication. There are several reasons for this: a complex history of ideas suggesting little common understanding of the notion of social justice, the focus of international human rights adjudication on individual rather than constitutional justice, and the priority of liberty rights over equality rights. Yet, the domination of the liberal over the social in international human rights adjudication has started to change. The article shows how the social justice concern is beginning to be incorporated into IHRL by judicial interpretation of international equal protection and nondiscrimination law (international equal protection law, IEPL). Integrating the social justice concern into IEPL is a legitimate yet transformative step as it increases judicial discretion at the international level. More than many other human rights, socioeconomic equality is highly context-specific and depends on a complex factual assessment of the local circumstances. This exacerbates the institutional legitimacy challenge levelled against international human rights courts. However, the article argues that the legitimacy challenge can be alleviated by focusing more on procedural rather than a substantive international review.
\end{abstract}

Keywords: adjudication; international human rights law; non-discrimination; social justice; socioeconomic inequality

\section{Introduction}

There is ample evidence that several OECD countries face a New Social Question. There is a widespread belief that the globalized market economy is 'rigged in favour of vested interests' and that the governing elites holding political and economic power 'no longer serve the interests of the ordinary folk'. ${ }^{1}$ In this situation, appeals to the ideal of social justice are gaining ground. One can broadly distinguish between two elements of social justice: the protection of the material wellbeing of individuals (freedom from want/absence of poverty) and socioeconomic equality. ${ }^{2}$

*I am grateful to Anne Peters and the participants of her 'Dienstagsrunde' at the Max Planck Institute for Comparative Public Law and International Law, and to the Faculty of the Fletcher School for excellent comments on an earlier version of this article. Many thanks to Alexandra Hansen and Una Schamberger for outstanding research assistance.

'‘Millennial socialism', The Economist, 16 February 2019, at 9-10, available at www.economist.com/leaders/2019/02/14/ millennial-socialism; J. Stiglitz, The Price of Inequality (2012); B. Milanovic, Global Inequality (2016).

${ }^{2}$ A. Peters, 'Global Constitutionalism: The Social Dimension', in T. Suami, A. Peters, D. Vanoverbeke and M. Kumm (eds.), Global Constitutionalism from European and East Asian Perspectives (2018), 277, at 291-7.

(c) The Author(s), 2022. Published by Cambridge University Press. This is an Open Access article, distributed under the terms of the Creative Commons Attribution licence (https://creativecommons.org/licenses/by/4.0/), which permits unrestricted re-use, distribution, and reproduction in any medium, provided the original work is properly cited. 
A question not often posed is: does international human rights law (IHRL) have anything to say about these elements of social justice?

The first element, the protection of the individuals' material wellbeing and the protection against extreme poverty, has been on the international human rights (IHR) agenda for some time. ${ }^{3}$ Major IHR treaties such as the International Covenant on Economic, Social and Cultural Rights (ICESCR) on the universal level and the European Social Charter (ESC) on the regional level serve to protect individuals' material wellbeing. ${ }^{4}$ In addition, sectoral international social law, for example, the International Labour Organization (ILO) Conventions, protect workers' rights and interests. ${ }^{5}$

The second element of social justice, socioeconomic equality, has, so far, lived a shadow existence in IHRL. ${ }^{6}$ All major IHR treaties now guarantee equal protection or non-discrimination. Importantly, these norms address (in)equalities within the state and are addressed to state organs as duty bearers and non-state actors as rights holders. ${ }^{7}$ Even so, as will be explained below, IHRL norms are generally not designed to capture problems of domestic socioeconomic inequality, i.e., the inequality between the haves and the have-nots within society. ${ }^{8}$

This indifference of IHRL towards socioeconomic inequality is starting to change, however. ${ }^{9}$ As socioeconomic inequality within the state can have an adverse effect on the enjoyment of important international public goods (including international peace and security, the environment, global trade), it has the potential to emerge as a high-profile concern also of IHRL. Notably, domestic inequality was recently identified as an international concern within the UN 2030 Agenda for Sustainable Development. ${ }^{10}$ Furthermore, social inequality arising from global climate change, economic globalization, migration, and pandemics is becoming visible. All of these new sources of social inequalities also require a response within the law. ${ }^{11}$ In particular, global crises (such as the global economic crisis of September 2008, the SARS-COV-2 Pandemic) tend to exacerbate existing domestic economic inequalities, making the need to react even more urgent. ${ }^{12}$ In light of rising inequality within states, the (former) UN Special Rapporteur on extreme poverty and human rights, Magdalena Sepúlveda Carmona, demanded remedies against discrimination based on the socioeconomic status of individuals. ${ }^{13}$ Furthermore, in its recent General Comment on equality and non-discrimination, the Committee on the Rights of Persons with

\footnotetext{
${ }^{3}$ In 1992, the UN General Assembly declared in Resolution 47/196, adopted on 22 December 1992, that 17 October would be the International Day for the Eradication of Poverty. Ending poverty is also listed in the UN Millennium Development Goals, available at www.un.org/millenniumgoals/bkgd.shtml. The Second and Third United Nations Decade for the Eradication of Poverty (2008-2017 and 2018-2027 respectively), were implemented with the objective to address poverty in an efficient and co-ordinated manner. See UN Doc. A/C.2/73/L.9.

${ }^{4}$ Preamble to the International Covenant on Economic, Social and Cultural Rights, 16 December 1966, General Assembly resolution 2200A (XXI) ('freedom from ... want'); European Social Charter (revised), 3 May 1996 (ETS No. 163) ('improve their standard of living and their social well-being').

${ }^{5}$ www.ilo.org/global/standards/subjects-covered-by-international-labour-standards/lang-en/index.htm.

${ }^{6}$ See Peters, supra note 2, at 293.

${ }^{7}$ For details see below Section 3.1.

${ }^{8}$ Ibid.

${ }^{9}$ For a recent assessment see J. Dehm, B. Golder and J. Whyte, 'Introduction: “Redistributive Human Rights?” symposium', (2020) 8 London Review of International Law 225.

${ }^{10}$ UNGA Res. A/RES/70/1, 21 October 2015, goal no. 10. See also UNGA Res A/RES/66/288, 11 September 2012, annex para. 4.

${ }^{11}$ UNGA Res. A/RES/69/183, 6 February 2015, Preamble.

${ }^{12} \mathrm{OECD}$, 'Crisis squeezes income and puts pressure on inequality and poverty', May 2013, available at www.oecd.org/els/ soc/OECD2013-Inequality-and-Poverty-8p.pdf; M. Fisher and E. Bubola, 'As Coronavirus Deepens Inequality, Inequality Worsens Its Spread', New York Times, 15 March 2020, available at www.nytimes.com/2020/03/15/world/europe/ coronavirus-inequality.html.

${ }^{13} \mathrm{HRC}$, Final draft of the guiding principles on extreme poverty and human rights, submitted by the Special Rapporteur on extreme poverty and human rights, Magdalena Sepúlveda Carmona, UN Doc. A/HRC/21/39, 18 July 2012, \$ 68(d), at 13; $\$ 88(\mathrm{c})$, at 21 .
} 
Disabilities (CRPD) made clear that 'inclusive equality' includes 'a fair redistributive dimension to address socioeconomic disadvantages'. ${ }^{14}$

In the literature, two main positions on the role of IHRL in dealing with domestic socioeconomic inequality have emerged. ${ }^{15}$ According to a first position (held, for example, by Philip Alston, Margot E. Salomon, and others), socioeconomic inequality (at least in its extreme forms) is incompatible with IHRL norms as they currently are and must be addressed as a human rights problem. ${ }^{16}$ Proponents of a second position (held, for example, by Samuel Moyn and - for different reasons - also by Susan Marks) are sceptical that problems of socioeconomic inequality can be solved through reliance on human rights and human rights protection mechanisms. ${ }^{17}$ In particular, Moyn doubts that human rights are 'fit for use' regarding socioeconomic inequalities, pointing to an alleged toothlessness of human rights in respect of redistribution from the rich to the poor. ${ }^{18}$ In history, according to Moyn, it was strong governmental power that exerted an equalizing force, not the critique of power through rights. ${ }^{19}$ From a different angle, Marks criticizes the inability of protection mechanisms to target the 'real' roots of human rights violations and social injustice. ${ }^{20}$

The literature lacks an assessment of the potential of positive IHRL to accommodate claims to socioeconomic equality, taking into account the judicial interpretation of these rights. To fill that gap, this article examines to what extent positive international equal protection law (IEPL) can offer a response to domestic socioeconomic inequality. In general, IEPL encompasses two types of equality norms: equal protection clauses (for example, Article 26 ICCPR, Article 24 ACHR) and non-discrimination clauses (Article 2(2) ICESCR, Article 14 ECHR). ${ }^{21}$ The article employs a comparative methodology, relying on four major international human rights instruments (ICESCR, ICCPR, ACHR, and ECHR). Furthermore, it contextualizes the legal element within the broader discourse on equality within political philosophy. The central argument is that the integration of socioeconomic inequality into IEPL would be a step that is desirable on normative grounds but deeply transformative doctrinally with significant repercussions also on the procedure of international human rights adjudication. ${ }^{22}$

As a limitation, it should be noted that this article does not deal with the related pressing issue of global (in)equality (equality between states and equality between individuals in different states) ${ }^{23}$ Instead, the present analysis is limited to jurisprudence concerned with domestic socioeconomic equality. ${ }^{24}$ In addition, this article is limited to the analysis of the IHR practice on

\footnotetext{
${ }^{14}$ CRPD, General comment no. 6 (2018) on equality and non-discrimination, UN Doc. CRPD/C/GC/6, 26 April 2018, §11, at 3 .

${ }^{15}$ Brinks, Dehm and Engle, 'Human Rights and Economic Inequality', (2019) 10 Humanity 363, at 363-75.

${ }^{16}$ Report of the Special Rapporteur on extreme poverty and human rights, UN Doc. A/HRC/29/31, 27 May 2015, para. 48; M. Salomon, 'Why Should it Matter that Others Have More? Poverty, Inequality, and the Potential of Human Rights Law', (2011) 37 Review of International Studies 2137.

${ }^{17}$ S. Moyn, 'A Powerless Companion: Human Rights in the Age of Neoliberalism', (2014) 77 Law and Contemporary Problems 147; S. Moyn, 'Human Rights and the Age of Inequality', OpenDemocracy, 27 October 2015, available at www. openglobalrights.org/human-rights-and-age-of-inequality/ (human rights are 'simply not fit for use in the socioeconomic domain'). S. Marks, 'Human Rights and Root Causes', (2011) 74 Modern Law Review 57.

${ }^{18}$ S. Moyn, Not Enough: Human Rights in an Unequal World (2018), 218.

${ }^{19}$ Ibid., at $218-19$.

${ }^{20}$ See Marks, supra note 17 , at $71-4$.

${ }^{21}$ T. Altwicker, Menschenrechtlicher Gleichheitsschutz [International Equal Protection Law] (2011), at 497.

${ }^{22}$ The purpose of this article is to give a normative account of IEPL (normative in a double sense of providing arguments from political philosophy and positive international human rights law). It does not aim to give a socio-legal account of the (lack of) socioeconomic equality in IHRL and only briefly touches upon ideological reasons (in Section 2.2).

${ }^{23}$ For an overview on recent works see J. v. Bernstorff, 'International Law and Global Justice', (2015) 26 EJIL, at 279.

${ }^{24}$ This is motivated by the fact that IHRL is still largely 'state-centred' law, see T. Altwicker, 'Transnationalizing Rights: International Human Rights Law in Cross-Border Contexts', (2018) 29 EJIL 581, at 583 (also for extensions). It is, of course, acknowledged that questions of social justice, today, often involve a transnational or international dimension (for example, tolerating poor working conditions abroad by a multinational company).
} 
domestic socioeconomic equality; for reasons of lack of space, it only briefly surveys the engagement of national courts with socioeconomic equality. Furthermore, the geographical scope of the inquiry is principally Europe, with some attention to American practice.

The article proceeds as follows. Section 2 traces the conceptual development of social justice in the Western history of ideas, discusses the reasons why it has been absent from the IHRL agenda, and outlines an argument for why it should be included now. Section 3 addresses the problem of how IEPL may accommodate the problem of socioeconomic inequality and whether this is a matter for international courts to resolve at all. From a broader perspective, Section 4 assesses the chances of integrating socioeconomic equality into IHRL.

\section{Internationalizing social justice?}

This section outlines the concept of social justice, traces its development in Western history of ideas, and discusses the reasons for adding socioeconomic (in)equality to the international human rights agenda.

\subsection{Social justice in the history of ideas}

The increased willingness of IHR bodies to turn domestic social justice into an international concern takes place against a centuries-old conceptual development background. According to a prominent current philosophical definition, social justice is about the fair distribution of socioeconomic goods within society. ${ }^{25}$ Socioeconomic goods include 'social goods' (such as access to political office, health care, education, shelter ${ }^{26}$ and 'economic goods' referring to marketable resources (e.g., income, property, other assets). ${ }^{27}$ Social justice is a term used synonymously with 'distributive justice', a concept often found in philosophy. ${ }^{28}$ The history of ideas elucidates conceptual continuities and discontinuities that can inform the present debate on integrating social justice into the international human rights agenda. The conceptual development of social justice can be traced at least as far back as to Aristotle and, to a lesser degree, also to Cicero. ${ }^{29}$ The first central impulse for the conceptual development comes from Aristotle's discussion of social or - as he called it - distributive justice in his Nicomachean Ethics and his Politics. ${ }^{30}$ For Aristotle, social justice had to do with the correct distribution of socially produced goods, such as 'honour, wealth, and the other divisible assets of the community'. ${ }^{31}$ This passage is misleading because it seems to imply that Aristotle had a broad concept of the social goods to be distributed, including socioeconomic goods. This was not in fact, the case. Aristotle did not address the economic inequality of citizens as a problem of social justice, nor did he discuss the idea that the have-nots may have legitimate distributive claims against their fellow wealthy citizens. ${ }^{32}$ He limited the objects of social justice to socially produced goods with a public status such as public office and rewards for public service. As an operational principle of social justice, Aristotle identified - in modern terminology - a desert- or merit-based proportionality: he advocated a proportional distribution of social goods based on individual merit, acknowledging, however, that 'merit' is defined relative to the prevailing political system: while

\footnotetext{
${ }^{25}$ D. Miller, Principles of Social Justice (1999), at 1-20.

${ }^{26}$ Alston, A/HRC/29/31 2015, para. 6.

${ }^{27}$ Ibid., para. 5 .

${ }^{28} \mathrm{UN}$, Department of Economic and Social Affairs, 'Social Justice in an Open World: The Role of the United Nations', 2006, ST/ESA/305, available at www.un.org/esa/socdev/documents/ifsd/SocialJustice.pdf.

${ }^{29}$ For earlier notions of socioeconomic justice see M. Ishay, The History of Human Rights (2008), at 35-40.

${ }^{30}$ To be exact, Aristotle was able to rely on some scattered references to distributive justice in Plato's late work, see Plato, Laws (1926), 697b, 744b.

${ }^{31}$ Aristotle, The Nicomachean Ethics (1926), at 267.

${ }^{32}$ S. K. Vaughan, Poverty, Justice, and Western Political Thought (2008), at 20.
} 
in democracies, merit is identified with free birth, oligarchies tend to equate merit with wealth. ${ }^{33}$ Aristotle did not see that considerations of justice itself may require the redistribution of goods by the community. ${ }^{34}$ Justice, including social justice, remained a virtue of the individual (and not a characteristic of a state or its institutions). However, Aristotle clearly saw that socioeconomic equality fostered the goal of political stability. Indeed, Aristotle and before him, Plato, described the political dimension of socioeconomic equality: as Noam Chomsky writes, Aristotle understood that a '[f]unctioning democracy presupposes relative equality in access to resources - material, informational, and other' ${ }^{35}$ It was Aristotle who emphasized the idea of equal citizenship. Individuals have a claim to a share in the goods produced by that political community proportionate to their contributions (to the end of the polis). ${ }^{36}$ Plato had insisted that socioeconomic inequality - extreme poverty and excessive wealth - were sources of great political instability and defended a model of strict egalitarianism, eliminating the institution of private property for the ruling classes in the ideal city-state outlined in his Republic. ${ }^{37}$ Indeed, Aristotle suggested that democracies establish some sort of public assistance scheme for the needy to enable them to get out of poverty. ${ }^{38}$

The second important impulse regarding social justice stems from Cicero's De officiis. Cicero's perspective was that of a lawyer-philosopher who, in contrast to Aristotle, looked at the issue in terms of (enforceable) duties. According to Cicero, the distribution of social goods was not a problem of justice, which for him only entailed the negative duties of 'do no harm' and 'respect for private and communal property'. ${ }^{39}$ Instead, Cicero distinguished between justice (justitia) and beneficence (beneficientia). ${ }^{40}$ While acts of justice entail negative duties which are legally required from anyone, there is considerable flexibility regarding the realization of beneficence. ${ }^{41}$ Indeed, Cicero's distinction has repercussions to this day. In a recent case, the Federal Magistrates Court of Australia used Cicero's distinction to argue that an act of grace payment required the claimant to show that such a payment was a matter of justice, not just a matter of charity. ${ }^{42}$ Finally, in line with the Aristotelian conception of distributive justice, Cicero demanded that the distribution of goods be merit-based. ${ }^{43}$

During the Middle Ages, the Aristotelian concept of social justice was fused with the JewishChristian doctrine of charity. Indeed, a subjective right of members of the lower class to be provided with material goods had, early on, emerged in the Talmud, the collection of Jewish laws. It "prescribes exactly how "charitable" funds are to be collected and distributed, including the appointment of gabbaim, or tax collectors, to administer the system'. ${ }^{44}$ The Jewish idea of charity was incorporated into the Bible and greatly influenced the Christian tradition. ${ }^{45}$ The fundamental question of whether providing aid to the poor was an act of justice or an act of charity was discussed by medieval theologians and canonists. ${ }^{46}$ By the beginning of the thirteenth century,

\footnotetext{
${ }^{33}$ Aristotle, supra note 31 , at 269.

${ }^{34}$ S. Fleischacker, A Short History of Distributive Justice (2004), at 20.

${ }^{35}$ N. Chomsky, Profit over People: Neoliberalism and Global Order (1999), at 131.

${ }^{36}$ F. Miller, 'Sovereignty and Political Rights', in O. Höffe (ed.), Aristoteles: Politik (2001), 107, at 111.

${ }^{37}$ Plato, Republic (2013), at 337.

${ }^{38}$ Aristotle, The Politics (1932), at 511.

${ }^{39}$ Cicero, On Duties (1913), at 21-3.

${ }^{40}$ Ibid., I.20-45, III.21-28.

${ }^{41}$ M. Nussbaum, 'Duties of Justice, Duties of Material Aid: Cicero's Problematic Legacy', (2000) 8 Journal of Political Philosophy 176, at 185-7; see Fleischacker, supra note 34, at 21.

${ }^{42}$ Clement v. Minister for Finance \& Deregulation [2009] FMCA 43 (30 January 2009), paras. 28-31.

${ }^{43}$ Cicero, supra note 39 , at 47.

${ }^{44}$ W. I. Trattner, From Poor Law to Welfare State (1999), at 3.

${ }^{45} \mathrm{G}$. Handel, Social Welfare in Western Society (2009), at 47.

${ }^{46}$ B. Tierney, Medieval Poor Law: A Sketch of Canonical Theory and Its Application in England (1959), at 35.
} 
canonist lawyers had developed a right to assistance of the needy, to be provided by the better off. ${ }^{47}$ Importantly, poverty was not considered a crime in medieval society. ${ }^{48}$ At the time, the church was charged with administering social aid to the poor, and it was ultimately the parish priest who was responsible for doing so. ${ }^{49}$

At the turn of the sixteenth century, and certainly, throughout the seventeenth century, social justice became discussed and redefined within the conceptual framework of modern statehood, characterized by the territorial fixation of authority, an increase in public (permanent, impersonal) institutions, a growing caste of public servants and the emphasis on the rule by law (rather than the rule by tradition). ${ }^{50}$ In particular, the system of social aid became administered by civil authorities. ${ }^{51}$ The notions of 'subjective rights' and 'property', which are fundamentally associated with the rise of modern statehood, reconfigured the debate on social justice. An early towering figure to discuss distributive justice in the modern framework was Hugo Grotius. ${ }^{52}$ It was Grotius who expressed the idea of justice through a conception of subjective rights: essentially, the notion of a natural right (in the strict sense) refers to the faculty 'which a Man has to his $o w n,{ }^{53}$ It is, thus, a conception of property (understood in a broad sense) that lies at the heart of Grotius' notion of a subjective right. ${ }^{54}$ The protection of this right in the strict sense, which is legally enforceable, constitutes the proper task of the political community. ${ }^{55}$ Grotius framed the enforceable, legal sphere of the subjective right ('expletive justice') very narrowly and distinguished it from the domain of 'attributive justice. ${ }^{56}$ The latter is about goods that are 'beneficial to others' (Grotius lists liberality, mercy, and proper administration of government - to which no subjective right corresponds). ${ }^{57}$ In the advent of the French Revolution, it was Jean-Jacques Rousseau who formulated the idea that freedom and socioeconomic equality are interrelated. A legitimate state, Rousseau argued, cannot exist without both - freedom cannot exist without equality. The laws must be so arranged that 'no citizen be so very rich that he can buy another, and none so poor that he is compelled to sell himself. ${ }^{58}$ As Samuel Moyn writes, it was the idea of republicanism coupled with Rousseau's stigmatization of excessive wealth that made the French Revolution possible. ${ }^{59}$

While the social justice debate of the nineteenth century had focused on society, the market, and questions of distribution, the twentieth-century discussion emphasized the state's role in catering for the socioeconomic welfare of the individual. Principles of social justice became a yardstick with which to assess the operation of institutions. In the late 1950s, John Rawls made a fresh start when he formulated two principles of justice - bringing together elements of liberty and equality, including socioeconomic equality. ${ }^{60}$ However, his theory left the precise connection and interaction between liberty and socioeconomic equality curiously open. ${ }^{61}$ According to

\footnotetext{
${ }^{47}$ Ibid., at 36 (quoting Guido de Baysio's commentary on the Decretum: 'Say briefly it is a precept to give alms from our superfluities and also to give to a man in extreme necessity ... To give alms in other circumstances is a matter of counsel').

${ }^{48}$ See Trattner, supra note 44 , at 4 .

${ }^{49}$ Ibid., at 5.

${ }^{50}$ See, in more detail, the seminal texts by J. R. Strayer, On the medieval origins of the modern state (2005), at 23-6 and W. Reinhard, Geschichte der Staatsgewalt (2003), 125-209.

${ }^{51}$ See Trattner, supra note 44 , at 6.

${ }^{52}$ On Grotius see Fleischacker, supra note 34 , at 22-3.

${ }^{53} \mathrm{H}$. Grotius, The rights of war and peace (2005), I.1.5, at 138. Grotius' notion of a subjective right has its roots in Roman law and should not be confused with the modern idea of individual rights as freedoms from the state. For a nuanced account see $\mathrm{S}$. Kadelbach, 'Hugo Grotius', in S. Kadelbach, T. Kleinlein and D. Roth-Isigkeit (eds.), System, Order, and International Law (2017), 134, at 144.

${ }^{54} \mathrm{Ibid}$.

${ }^{55}$ Ibid., I.2.1, at 184 .

${ }^{56}$ Ibid., I.1.8, at 142 .

${ }^{57}$ Ibid.

${ }^{58}$ J.-J. Rousseau, Of the Social Contract (1997), Book II, Ch. 11, at 78.

${ }^{59}$ See Moyn, supra note 18 , at $20-1$.

${ }^{60}$ J. Rawls, 'Justice as Fairness', (1958) 67 Philosophical Review 164, at 165-6.

${ }^{61}$ J. Rawls, Justice as Fairness: A Restatement (2001), at 49.
} 
Rawls, the main reason for regulating socioeconomic inequalities lies in the political idea of citizens viewing one another as equals. ${ }^{62}$ Rawls saw that excessive socioeconomic inequalities need to be avoided because of their unfair, destabilizing social effects and the inefficiencies created. ${ }^{63}$ In particular, Rawls wanted to prevent domination of one part of society over another (political inequality) and feelings of inferiority in society. ${ }^{64}$ Famously, Rawls identified the conditions under which social and economic inequalities are acceptable: inequalities, in order to be justified, must be compatible with the principle of fair equality of opportunity (concerning offices and positions). Rawls demanded fair and not merely formal equality of opportunity. ${ }^{65}$ Subordinate to this, inequalities (concerning income and wealth) must be compatible with the difference principle. ${ }^{66}$ His difference principle establishes a fundamental presumption in favour of equal distribution of income and wealth: any unequal distribution of economic goods requires justification, the only possible justification being the enhancement of the social position of those who are least well-off ('the least-advantaged') in society. ${ }^{67}$ The difference principle, therefore, suggests an asymmetrical approach to equality and non-discrimination, requiring that the effects on the socially disadvantaged be taken into account. ${ }^{68}$ Rawls' principles of justice pertain to what he calls the 'basic structure' (institutions); they do not allow for evaluation of the justice or injustice of individual actions. ${ }^{69}$ Consequently, Rawls distinguished between 'distributive justice' (the object of his second principle of justice) and 'allocative justice' (which is not part of his theory). ${ }^{70}$

Recently, Amartya Sen and Martha Nussbaum took up the idea of social justice and socioeconomic equality. In contrast to Rawls, they focus on the 'capabilities' of individuals rather than the distribution of goods. They show that autonomy and self-realization cannot be viewed in isolation from socioeconomic guarantees and equality. Sen famously criticized the Rawlsian difference principle for its sole focus on 'means' (or goods), 'without taking into account the wide variations [people] have in being able to convert primary goods into good living. ${ }^{71}$ Sen gave the example of a disabled person who can do far less with the same income as a non-disabled person. ${ }^{72}$ This motivated Sen's departure from the Rawlsian notion of primary goods and his focus on the 'actual assessment of freedoms and capabilities' instead. ${ }^{73}$ The capabilities approach is based on the idea of assessing the quality of life by 'what [people] are actually able to do and to be'. ${ }^{74}$ This suggests empirical measurability: indicators can be used to determine how successful a state is, for example, in eliminating forms of discrimination. ${ }^{75}$

The three takeaways from the debate on social justice in political philosophy relevant to the legal discourse are the following: first, and most importantly, the recent philosophical debate has increasingly stressed the link between concrete individual liberty and socioeconomic inequality. Second, a recurrent theme in the history of ideas is whether the distribution of socioeconomic goods should be viewed under the lens of charity or under the lens of justice. Third, the connection

\footnotetext{
${ }^{62}$ Ibid., at $130-2$.

${ }^{63}$ Ibid., at 131 .

${ }^{64}$ Ibid., at $130-1$.

${ }^{65}$ Ibid., at $43-4$.

${ }^{66}$ See his second principle of justice in ibid., at $42-3$.

${ }^{67}$ Ibid., at $42-3,57-65$.

${ }^{68} \mathrm{On}$ an asymmetrical conception of equal protection law see below Section 3.2.3.

${ }^{69}$ P. Van Parijs, 'Difference Principles', in S. Freeman (ed.), The Cambridge Companion to Rawls (2003), 200 , at 222.

${ }^{70}$ See Rawls, supra note 61, at 50: 'Allocative justice' concerns the problem of 'how a given bundle of commodities is to be distributed, or allocated, among various individuals whose particular needs, desires, and preferences are known to us, and who have not cooperated in any way to produce those commodities'.

${ }^{71} \mathrm{~A}$. Sen, The Idea of Justice (2010), at 65-6.

${ }^{72}$ Ibid., at 66 .

${ }^{73}$ Ibid.

${ }^{74}$ M. Nussbaum, Frontiers of Justice (2007), at 73.

${ }^{75}$ S. Fukuda-Parr, 'The Metrics of Human Rights: Complementarities of the Human Development and Capabilities Approach', (2011) 12 Journal of Human Development and Capabilities 73.
} 
between socioeconomic inequality and political instability was made early on in the history of ideas.

\subsection{Absence of socioeconomic equality in IHRL}

The growing sensitivity of IHRL to problems of socioeconomic equality, the difference between the haves and the have-nots in society, is a novel and - given the historical predominance of civil and political rights - a somewhat unlikely phenomenon. While a critical account of the history of IHRL is beyond the scope of this article, it is clear that the long neglect of socioeconomic equality as a human rights' phenomenon resonated well with Western liberal thought. Western political thought upheld, for a long time, the narrative of the unequivocal good of individual autonomy, emphasizing the responsibility of individuals for their own wellbeing (I. Kant, J. Locke), trusting the 'freedom' of market forces (F. Hayek), or leaving the consequences of excesses of individual freedoms largely undiscussed (J. Rawls). Viewed from this angle, the long silence of IHRL on socioeconomic equality is hardly surprising. It also reflected the ideological divide of the Cold War, the disagreement about the nature and implementation of rights, and the controversy about the instrumental value of rights in regulating the economic sphere. While the Universal Declaration of Human Rights of 1948 (UDHR) had included civil and political rights as well as social and economic rights in a single document, great ideological divisions loomed between the superpowers of the Cold War about which category of rights to be given priority. ${ }^{76}$ The Soviet representatives favoured social and economic rights over civil and political rights, in contrast to the American representatives. ${ }^{77}$ The decision to include both categories of rights in two separate binding international covenants (ICESCR and ICCPR) reflected that ideological division and fostered, notably in the West, those forces that viewed socioeconomic rights as being 'second-class' rights at best.

After the fall of socialism, the continued absence from the IHRL agenda of socioeconomic concerns, including equality, can no longer be sufficiently explained by the ideological divide argument. Beyond the ideological divisions, there have been persistent reservations on a doctrinal level against the inclusion of socioeconomic rights, and by extension, socioeconomic equality into IHR treaties. Eleanor Roosevelt remarked that socioeconomic rights required a different implementation method and were not as justiciable as civil and political rights. ${ }^{78}$ Similarly, in the context of the drafting of the ECHR, it was asserted that socioeconomic rights were excluded from the text because they were 'too controversial and difficult' and 'their inclusion would jeopardize the acceptance of the Convention. ${ }^{79}$ Thus, it is not surprising that international human rights courts and commissions have in the past hesitated to touch problems concerning the distribution of socioeconomic goods within societies and, if they do, they grant a wide margin of appreciation to the states. ${ }^{80}$ The soft formulations in some international instruments contribute to a lack of commitment, e.g., Article 2(1) ESC states that ' $[\mathrm{t}$ ] he Parties undertake ... to consider themselves bound by the obligations laid down in the following articles and paragraphs'.

\footnotetext{
${ }^{76}$ See Ishay, supra note 29 , at 221.

${ }^{77}$ Ibid.

${ }^{78}$ E. Roosevelt, 'Statement on Draft Covenant on Human Rights', at 168 (quoted in Ishay, ibid., at 223).

${ }^{79}$ Preparatory Commission of the Council of Europe, Committee of Ministers (1975), at 116 (Maxwell-Fyfe).

${ }^{80} \mathrm{The}$ ECtHR grants Contracting States, in its long-standing caselaw, 'a wide margin ... when it comes to general measures of economic or social strategy', EctHR, Stec and others v. United Kingdom, Appl. No. 65731/01, Judgment of 12 April 2006, para. 52. In some cases, the IACtHR has not explicitly, but arguably implicitly, recognized a margin of deference in taking special consideration of certain national decisions in its own examination of a case. This was, e.g., the case in IACHR, Report 38/09, Case 12.670, National Association of Ex-Employees of the Peruvian Social Security Institute et al., Peru (27 March 2009), regarding a social security system reform in Peru. The HRC, too, defers to the domestic legislator in socioeconomic matters: See Mahuika v. New Zealand, Comm. 547/1993, UN Doc. CCPR/C/70/D/547/1993 (2000), paras 9.10-9.11, where the circumstantial context was relevant for the limitation of Maori rights in commercial fisheries.
} 
Finally, controversy reigns over the instrumental value of rights for pursuing social and economic justice in general. ${ }^{81}$ In constitutional democracies, the economy is commonly viewed as a field primarily left to the competition of non-state actors. ${ }^{82}$ Since, according to conventional IHRL doctrine, non-state actors are not duty bearers, in other words, these rights do not have direct horizontal application. ${ }^{83}$ Given that the private sector is the largest producer of socioeconomic inequality, it seems - at first sight - that the reach of rights to correct this is limited. However, as will be shown below (in Section 3.2.3), IHRL can be of indirect help in paving the way towards greater socioeconomic equality domestically.

\subsection{Integrating social justice into the international human rights agenda}

Is social justice a human rights problem? The following section discusses the arguments made for integrating social justice into the international human rights agenda and links the philosophical and legal debates. ${ }^{84}$

\subsubsection{Concrete individual freedom}

The emerging engagement with social justice in IHRL mirrors the philosophical debate's shift away from concentrating on the abstract distribution of socioeconomic goods to securing concrete individual freedom. Safeguarding concrete individual freedom is an accepted goal of IHRL. ${ }^{85}$ Autonomy and self-realization of the individual that lie at the heart of civil and political rights must be viewed as depending on socioeconomic conditions that, to some extent, need to be provided for by the state. ${ }^{86}$ For example, the individual's right to speak out, to make use of their property, or to vote for a government, etc. are of mere ornamental value to an individual who is unable to read or write or who does not have the financial means to acquire possessions of her own. The state, thus, must provide for basic education to render some civil and political rights practical and effective. This interrelatedness of freedom and socioeconomic equality was spelled out early on in the philosophical debate (for example, by Rousseau). More recently, Amartya Sen and Martha Nussbaum's capabilities approach has shifted the focus from abstract opportunities and means (as in Rawls' Theory of Justice) to concrete (or actual) freedom. ${ }^{87}$ In this view, socioeconomic equality is beneficial or even necessary for achieving genuine freedom. As with the goal of social inclusion and political stability, socioeconomic equality is not valued for itself but for being instrumental in pursuing other values. For example, empirical studies have shown that income inequality has a negative impact on education and social mobility. ${ }^{88}$

With the shift to promoting concrete freedom as an end of justice and the shift to actual equal opportunities, the goals of sufficiency and socioeconomic equality become powerful ideas with consequences for all areas of law, including IHRL. In a way, IHRL, at least in theory, accepted the interconnectedness of liberty, equality, and sufficiency early on. The notions of 'indivisibility, interdependence, and interrelatedness' of human rights have been around at least since the 1950s

\footnotetext{
${ }^{81}$ On the 1993 World Conference on Human Rights as a lost chance to establish redistributive concerns on the IHRL agenda see R. Burke, 'The 1993 World Conference on Human Rights and the retreat of a redistributive rights vision', (2020) 8 London Review of International Law, at 233.

${ }^{82}$ F. A. Hayek, The Road to Serfdom (2001).

${ }^{83}$ J. H. Knox, 'Horizontal Human Rights Law', (2008) 102 AJIL 1, at 10-14.

${ }^{84}$ From a philosophical perspective see J. Song, 'Human rights and inequality', (2019) 47 Philosophy \& Public Affairs 347.

${ }^{85}$ See the famous formula used by the ECtHR that Convention rights must be 'practical and effective', e.g., in ECtHR, Salduz v. Turkey, Judgment of 27 November 2008, Appl. no. 36391/02, para. 51.

${ }^{86}$ Report of the Special Rapporteur on extreme poverty and human rights, UN Doc. A/HRC/29/31, 27 May 2015, para. 18; UN CESCR, General comment No. 20, 2 July 2009, E/C.12/GC/20, para. 8.

${ }^{87}$ See the discussion in Section 2.1 .

${ }^{88} \mathrm{~B}$. Keeley, 'Income Inequality: The Gap between Rich and Poor', OECD Insights, 15 December 2015, available at dx.doi. org/10.1787/9789264246010-en, at 64-5.
} 
and newly gained ground after the collapse of socialism. ${ }^{89}$ In essence, the indivisibility thesis states that the set of universal values protected by human rights is more than the sum of its parts. There is no hierarchy between civil and political rights and economic, social, and cultural rights.

Furthermore, under the idea of indivisibility, governments may not resort to a 'pick and choose' procedure regarding the question of which human rights deserve protection and which do not. ${ }^{90}$ Finally, the indivisibility thesis suggests a harmonious interpretation in IHRL, taking rights contained in other international treaties as interpretive guidance. ${ }^{91}$

The UDHR embodies these ideas by translating, in a single international document, the ideals of liberty, sufficiency, and equality into subjective (but non-binding) rights. ${ }^{92}$ The connection between the 'social' dimension and the 'autonomy' dimension of human rights is made most explicit when the Declaration stipulates that '[e]veryone, as a member of society, has the right to social security and is entitled to [the] realization ... of the economic, social and cultural rights indispensable for his dignity and the free development of his personality'. ${ }^{93}$ Similarly, the EU Charter of Fundamental Rights stresses the foundational character of the indivisible, universal values of human dignity, freedom, equality, and solidarity. ${ }^{94}$ In recent times, the indivisibility idea of human rights gained new strength through its operationalization by IHR bodies in non-discrimination contexts. For example, in a recent General Comment, the UN Committee on the Rights of Persons with Disabilities (CRPD) relied on the notion of 'indivisibility' as a foundation of its 'human rights model of disability'. ${ }^{95}$ Individual members of the ECtHR referred to the notions of indivisibility and interdependence to argue for positive socioeconomic obligations of states and the absence of any hierarchy between the types of human rights. ${ }^{96}$ The CESCR considered indivisibility in cases concerning the equality of women and reproductive rights ${ }^{97}$ and discriminatory eviction practices. ${ }^{98}$ In sum, the indivisibility thesis is increasingly invoked by IHR bodies to argue for a more holistic perspective on the protection of human agency and autonomy, encompassing aspects of liberty, sufficiency, and equality (including socioeconomic equality).

\subsubsection{Social inclusion}

The philosopher John Rawls (as many had before him) pointed to the negative social impact of socioeconomic inequalities. According to Rawls, these are often accompanied by inequalities of social status that encourage those of lower status to be viewed both by themselves and by others as inferior', leading to 'serious evils' and 'great vices'. ${ }^{99}$ In this perspective, socioeconomic inequality is not intrinsically wrong or unjust but because of its negative social impact (fostering exclusion, feelings of inferiority, etc.). In recent times, IHRL has picked up on the idea of furthering social inclusion by providing for socioeconomic equality. For example, the ESC establishes ' $[w]$ ith a view to ensuring the effective exercise of the right to protection against poverty and social exclusion'

\footnotetext{
${ }^{89}$ Vienna Declaration and Programme of Action, Adopted by the World Conference on Human Rights in Vienna on 25 June 1993 (para. 5), available at www.ohchr.org/en/professionalinterest/pages/vienna.aspx. For the background see I. Leijten, Core Socio-Economic Rights and the European Court of Human Rights (2018), at 69-73.

${ }^{90} \mathrm{~F}$. Bouchet-Saulnier, Droits de l'homme, droit humanitaire et justice internationale (2002), at 23, 27 et seq.

${ }^{91}$ HRC, Yassin et al. v. Canada, No. 2285/2013, 7 December 2017, UN Doc. CCPR/C/120/D/2285/201, \$3.7; ECtHR, Cyprus v. Turkey, Appl. no. 25781/94, 12 May 2014, para. 23; Leijten, supra note 89, at 77.

${ }^{92}$ Preamble, Art. 1, Art. 2, Art. 3, Art. 7, Art. 22, Art. 23(2) and (3), Art. 25(1), Art. 26 UDHR.

${ }^{93}$ Art. 22 UDHR.

${ }^{94}$ Charter of Fundamental Rights of the European Union of 7 December 2000, OJ C326 (2012), 391.

${ }^{95} \mathrm{UN}$ Committee on the Rights of Persons with Disabilities, 26 April 2018, General Comment No. 6 (2018) on equality and non-discrimination, $\$ 9$.

${ }^{96}$ Individual opinion by Judge Albuquerque in ECtHR, Lopes de Sousa Fernandes v. Portugal, Appl. no. 56080/13, Judgment of 19 December 2017, para. 28.

${ }^{97}$ CESCR, S.C. and G.P. v. Italy, No. 22/2017, 7 March 2019, UN Doc. E/C.12/65/D/22/2017, \$ 8.1.

${ }^{98}$ CESCR, Ben Djazia et al. v. Spain, No. 5/2015, 20 June 2017, E/C.12/61/D/5/2015, § 15.4 .

${ }^{99}$ See Rawls, supra note 61, at 131.
} 
that the states must take positive measures to 'promote the effective access of persons who live or risk living in a situation of social exclusion or poverty, as well as their families, to, in particular, employment, housing, training, education, culture and social and medical assistance'. ${ }^{100}$ In the context of persons living with disabilities, the CRPD has advocated a model of 'inclusive equality', which is (partially) founded upon the 'fair redistributive dimension to address socioeconomic disadvantages'. ${ }^{101}$ States must adopt positive measures to achieve inclusive equality. ${ }^{102}$ In the context of disability, the Inter-American Court of Human Rights (IACtHR) in Ximenes Lopes declared that the link between the disability, on the one hand, and poverty and social exclusion, on the other, is direct and significant'. ${ }^{103}$ In a subsequent case, the IACtHR held that states are required to adopt positive measures to reverse the social exclusion of vulnerable groups (for example, members of indigenous communities).

Similarly, the ECtHR has relied on a social exclusion argument in relation to vulnerable groups. Since vulnerable groups have historically been subject to prejudice and discrimination with lasting consequences, they suffer from social exclusion. ${ }^{104}$ The social exclusion argument is used by the ECtHR to demand 'very weighty reasons' and to justify granting only a narrow margin of appreciation. ${ }^{105}$ However, so far, the ECtHR seems not to have made the link between socioeconomic inequality and social exclusion. In sum, some international human rights bodies recognize that socioeconomic equality is associated with social inclusion.

\subsubsection{Political stability?}

As outlined above, Plato, Aristotle, and later Rousseau identified excessive socioeconomic inequality as a driver of political instability. In a similar vein, the (former) UN Rapporteur on Extreme Poverty and Human Rights, Philip Alston, argued, based on empirical studies, that there are strong correlations between socioeconomic inequality and social unrest. ${ }^{106}$ The ECtHR has accepted 'political stability' as a legitimate concern in a case relating to the specific context of the right to vote (Article 3 Protocol 1 ECHR) and non-discrimination (Article 14 ECHR). ${ }^{107}$ In another political stability case, the ECtHR mentioned the prevention of disorder as a legitimate aim. ${ }^{108}$ However, these are exceptional circumstances, as they mainly concern the justification of infringement of civil rights (not equality rights), and the connection between the measure and political stability was probably more evident. Presently, it seems unlikely that IHR bodies would justify the redistribution of socioeconomic goods based on political stability concerns. ${ }^{109}$

\section{Socioeconomic equality and international equal protection law}

This section shows that any attempt to give IEPL a social justice-oriented interpretation faces substantial doctrinal obstacles. These can, however, be overcome through progressive judicial interpretation.

\footnotetext{
${ }^{100}$ Art. 30 ESC (rev.).

${ }^{101}$ CRPD, 26 April 2018, General Comment No. 6 (2018) on equality and non-discrimination, para. 11.

${ }^{102}$ Ibid., para. 57.

${ }^{103}$ IACtHR, Ximenes Lopes v. Brazil, Judgment of 4 July 2006, para. 104.

${ }^{104}$ ECtHR, Cînța v. Romania, Appl. no. 3891/19, Judgment of 18 February 2020, para. 41 (regarding the mentally disabled). ${ }^{105}$ Ibid.

${ }^{106}$ Report of the Special Rapporteur on extreme poverty and human rights, UN Doc. A/HRC/29/31, 27 May 2015, para. 28.

${ }^{107}$ ECtHR, Oran v. Turkey, Appl. no. 28881/07, Judgment of 15 April 2014, para. 66.

${ }^{108}$ ECtHR, Zhdanov v. Russia, Appl. no. 12200/08 et al., Judgment of 16 July 2019, para. 160.

${ }^{109}$ This leads to a more general question: Are infringements upon civil rights of individuals (for example, the right to property) justified to promote socioeconomic equality (and with it, political stability)? This question must be left to further research.
} 


\subsection{Marginal role of socioeconomic equality in human rights law}

Socioeconomic equality, presently, only plays a marginal role within IHRL. The unequal distribution of socioeconomic goods is only explicitly addressed under IHRL in two situations: first, in the context of equal pay of men and women for equal work, ${ }^{110}$ and second relating to equal access to social security and social and medical assistance for nationals and non-nationals. ${ }^{111}$ Given this lack of specific protection, the human rights problem of socioeconomic equality needs to be captured, if at all, under the general norms of IEPL, i.e., the equal protection clauses and non-discrimination norms contained in the major human rights instruments.

\subsubsection{Socioeconomic equality in universal human rights protection mechanisms}

Under the universal instruments of IHRL, there is only scattered reference to socioeconomic equality. Even in the international human rights text that most evidently deals with economic and social interests, the ICESCR, socioeconomic equality has, so far, not played a larger role. The ICESCR protects equality concerns at several places, most importantly in Article 2(2) ICESCR, which contains a non-discrimination provision (accessory to the Covenant rights). ${ }^{112}$ None of the equality provisions figure prominently in the decisions of the UN Committee on Economic, Social and Cultural Rights (CESCR). ${ }^{113}$ Two cases decided under the non-discrimination provision (Article 2(2) ICESCR) did not concern socioeconomic inequality but other grounds of discrimination. ${ }^{114}$ Furthermore, an individual's socioeconomic status is not explicitly named as a discrimination ground in Article 2(2) ICESCR but could, potentially, be added as 'other status'. The marginal role of socioeconomic equality is no different under the ICCPR, which features two main equality provisions: Article 2(1) ICCPR stipulates an (accessory) non-discrimination right, and Article 26 ICCPR establishes an equal protection clause. ${ }^{115}$ Exceptionally, in the recent case of Siobhán Whelan v. Ireland (2017), the Human Rights Committee referred to the 'socioeconomic circumstances' of the complainant and found a violation of Article 26 ICCPR in a case concerning the termination of a non-viable pregnancy. ${ }^{116}$ In respect of the Roma community, the UN Committee on the Elimination of Racial Discrimination (CERD) has drawn a connection between the 'continued stigmatization of, and discrimination against Roma and their ongoing precarious socioeconomic situation.' ${ }^{\prime 17}$ While these examples show a growing awareness in international human rights bodies of the complex relationship between socioeconomic inequality and discrimination, the pressing problems caused by this link have not been adequately addressed under the universal human rights instruments.

\footnotetext{
${ }^{110}$ Art. 4(3) ESCR.

${ }^{111}$ Art. 12(4)(a) ESCR; Art. 13(4) ESCR.

${ }^{112}$ In addition, Art. 3 ICESCR stipulates equal protection for men and women, Art. 7(a)(i) ICESCR relates to equality in the context of work, Art. 7(c) ICESCR contains an equal opportunity provision in the context of employment, and, finally, Art. 10(3) ICESCR concerns the special context of children and young persons.

${ }^{113}$ There are only five hits of these norms in the database of the OHCHR (including two inadmissibility decisions), available at juris.ohchr.org/search/Documents. However, in recent years there seems to be an increased awareness for economic inequality at the UN Committee on Economic, Social and Cultural Rights, see K. H. Ragnarsson, 'Humanising not transformative? The UN Committee on Economic, Social and Cultural Rights and economic inequality in OECD countries 2008-19', (2020) 8 London Review of International Law 261.

${ }^{114}$ CESCR, López Rodriguez v. Spain, 4 March 2016, E/C.12/57/D/1/2013 (disability); CESCR, Trujiloo Colero v. Ecuador, 26 March 2018, E/C.12/63/D/10/2015.

${ }^{115}$ See Altwicker, supra note 21 , at 49-59,135.

${ }^{116}$ HRC, Siobhán Whelan v. Ireland, 11 July 2017, CCPR/C/119/D/2425/2014, § 7.12.

${ }^{117}$ The CERD adopted concluding observations in respect of Slovakia in 2013, CERD/C/SVK/CO/9-10, para. 10.
} 


\subsubsection{Socioeconomic equality in regional human rights protection mechanisms}

The situation is not much different with respect to regional human rights instruments. The InterAmerican Convention on Human Rights (ACHR) contains a right to non-discrimination in Article 1(1) ACHR and an equal protection clause in Article 24 ACHR. ${ }^{118}$ Despite prevailing extreme inequalities in American societies, the Inter-American human rights bodies have only recently taken up problems of socioeconomic inequality. ${ }^{119}$ Indirectly, it played a role in the case of Undocumented Migrants v. United States of America, decided by the Inter-American Commission on Human Rights (IACmHR). ${ }^{120}$ In this case, two undocumented workers successfully claimed that the United States violated their right to non-discrimination by failing to protect their labour rights assured under the American Declaration of the Rights and Duties of Man. However, rather than treating this as a case concerning socioeconomic inequality, the case was decided as immigration status-related discrimination. An explicit reference to socioeconomic status was made in the case of Gonzales Lluy v. Ecuador, however. ${ }^{121}$ Talía, a minor, tested positive for HIV after she had been given multiple contaminated blood transfusions. She was subsequently discriminated against by school officials and teachers and barred from attending primary school. Her family was evicted several times when landlords learned about her condition. The IACtHR found a violation, among others, of the non-discrimination clause in Article 1(1) ACHR in relation to the right to education in Article 13(1) ACHR. In this context, the IACtHR noted that:

[the] discrimination against Talía has been associated with factors such as being a woman, a person living with HIV, a person with disabilities, and a minor, and also her socio-economic status. These aspects made her more vulnerable and exacerbated the harm that she suffered. ${ }^{122}$

The Court effectively used socioeconomic status as another ground of discrimination, along with the conventional ones, to argue for the particular vulnerability of the minor in this case.

Under the ECHR, the main non-discrimination clause is contained in Article 14 ECHR. ${ }^{123}$ So far, socioeconomic inequality seems to have played only an implicit role in many non-discrimination cases. ${ }^{124}$ Judge Pinto de Albuquerque rightly criticized the Court's reluctance to address socioeconomic discrimination upfront in a dissenting opinion in the recent Garib v. the Netherlands case. ${ }^{125}$ The case concerned housing restrictions in a district of Rotterdam: the complainant was denied a residence permit for the district of her choice, partly because she was unemployed. Given that the case concerned the right to freedom of movement (Article 2(4) Protocol 4 ECHR), the Court could have applied the non-discrimination provision of Article 14 ECHR: the complainant was denied access to a public benefit (i.e., a housing permit) on the basis of her socioeconomic status. Nevertheless, the Court majority decided the case solely based on the weaker right to freedom of movement (with no violation found).

A similar pattern can be found in other cases as well. The recent case of Hudorovič and others $\mathrm{v}$. Slovenia concerned access of two Roma settlements to water. ${ }^{126}$ The case, thus, involved classic

\footnotetext{
${ }^{118}$ In addition, the ACHR provides for sectoral protection of equality interests, for example equal suffrage (Art. 23(1)(b) ACHR).

${ }^{119}$ Von Bogdandy, 'Überstaatlicher transformativer Konstitutionalismus: Bemerkenswertes vom Interamerikanischen System für Menschenrechte', (2019) 58 Der Staat 41, at 41 (naming, among others, 'social exclusion' and 'extreme inequality')

${ }^{120} \mathrm{IACmHR}$, Undocumented Migrants v. United States of America, 30 November 2016, Report No. 50/16, Case 12.834.

${ }^{121}$ IACtHR, Gonzales Lluy et al. v. Ecuador, 1 September 2015, No. 298 (2015).

${ }^{122}$ Ibid., $\$ 285$.

${ }^{123}$ In addition, Art. 1 Prot. 12 ECHR contains a general non-discrimination right applicable to all circumstances.

${ }^{124}$ ECtHR, Berger-Krall and Others v. Slovenia, Appl. no. 14717/04, Judgment of 12 June 2014.

${ }^{125}$ Dissenting opinion by Judge Pinto de Albuquerque in ECtHR, Garibv. the Netherlands, Appl. no. 43494/09, Judgment of 6 November 2017.

${ }^{126}$ ECtHR, Hudorovič and others v. Slovenia, Appl. no. 24816/14 et al., Judgment of 10 March 2020.
} 
socioeconomic goods, access to drinking water, and sanitation, and it essentially revolved around the existence and the scope of the state's positive obligations. As before, the Court decided the case on liberty grounds only, denying the need to assess the discrimination part (discrimination on ethnic and/or socioeconomic grounds). ${ }^{127}$ This is problematic because, as the European Commission against Racism and Intolerance (ECRI) has noted, Roma lack of full enjoyment of their civil rights is inextricably linked to their socioeconomic situation. ${ }^{128}$

\subsubsection{Socioeconomic equality in selected other jurisdictions}

In times of transnational judicial dialogue, international human rights courts and commissions look to other jurisdictions for guidance on legal questions, also concerning socioeconomic equality. ${ }^{129}$ The European Committee of Social Rights has referred to the socioeconomic status as a ground of discrimination in cases dealing with unequal access for women to abortion: if they are forced, by the domestic legislation, to make their own travel arrangements in order to have an abortion abroad, this constitutes (a form of indirect) discrimination because some will lack the financial means to do so. ${ }^{130}$ National practice can certainly provide guidance when designing an international response to domestic socioeconomic equality. However, because this article only deals with international practice on socioeconomic equality, reference to the practice of domestic courts can be brief. Rich case law on issues of socioeconomic equality can be found for Canada: recent cases before Canadian courts concerned, for example, the impact of retroactive decreases in child support obligations on the socioeconomic equality of women and children, ${ }^{131}$ or the impact of social assistance legislation on dependent family members of persons living in poverty. ${ }^{132}$ As a brief survey of cases on socioeconomic equality showed, domestic cases are commonly decided upon the ground of (indirect) gender discrimination or other suspect classifications, however, they do not rely on the socioeconomic status as a suspect ground of classification.

\subsection{Making socioeconomic equality justiciable}

\subsubsection{Socioeconomic inequality as discrimination}

Can socioeconomic inequality constitute discrimination? This question relates to the scope of IEPL norms. Although some international human rights courts and commissions (not least, the ECtHR) have in the last two decades started to give a more progressive reading to equality norms, there are still doctrinal hurdles to overcome to assimilate the level of protection offered by IEPL to that provided by civil and political rights. ${ }^{133}$ In particular, the narrower the scope of IEPL norms, the harder it is to capture problems of socioeconomic equality.

For a start, international equal protection clauses (Article 26 ICCPR, Article 24 ACHR) allow for a wider application than non-discrimination clauses (Article 2(2) ICESCR, Article 14 ECHR) for two reasons. First, in contrast to non-discrimination norms, international equal protection clauses have general applicability: they are not ancillary in the sense that they can be invoked independently from the substantive rights contained in the human rights text. Second, the

\footnotetext{
${ }^{127}$ Ibid., para. 162 .

${ }^{128}$ ECRI, Report on Greece adopted 2 April 2009, published 15 September 2009, para. 55; Council Recommendation of 9 December 2013 on effective Roma integration measures in the Member States, OJ C 378 of 24 December 2013, 1).

${ }^{129}$ See Peters, supra note 2, at 316.

${ }^{130}$ ESCR, IPPF EN) v. Italy, No. 87/2012, 10 September 2013, para. 190.

${ }^{131}$ Supreme Court of Canada, Felice Colucci v. Lina Colucci, pending, available at www.scc-csc.ca/case-dossier/info/sumsom-eng.aspx? cas $=38808$.

${ }^{132}$ Sparks v. Nova Scotia (Assistance Appeal Board), 2017 NSCA 82, available at www.canlii.org/en/ns/nsca/doc/2017/ 2017nsca82/2017nsca82.html?autocompleteStr=sparks\%20v\%20n\&autocompletePos=1.

${ }^{133}$ Notably, the non-discrimination norm of Art. 14 ECHR was considered as a 'second-class guarantee', see Wildhaber, 'Protection against Discrimination under the European Convention on Human Rights - A Second-Class Guarantee?', (2002) 2 BalticYIL 71.
} 
invocation of an equal protection clause is not dependent on a treatment based on certain grounds of discrimination. ${ }^{134}$ A look at Article 14 ECHR can help exemplify this difficulty of capturing socioeconomic inequality problems through non-discrimination norms: Article 14 ECHR is not an independent subjective right, but it is accessory to the other substantive rights in the sense that it requires the facts at issue to fall into the 'ambit' of a substantive Convention right. ${ }^{135}$ Unlike the ICCPR or the ACHR, the ECHR does not stipulate an equal protection clause. Although the ECtHR is relatively generous in affirming that an issue falls within the ambit of another right or freedom, this is nevertheless a significant hurdle in the present context, for the following reason: the text of the ECHR itself guarantees only civil and political rights, but not economic and social rights, although the ECtHR has started to shape a socioeconomic case law through judicial interpretation. ${ }^{136}$ Significantly, the ECtHR has extended the scope of non-discrimination protection to situations in which the state has voluntarily decided to provide for certain socioeconomic goods (e.g., a disability allowance). ${ }^{137}$ This extension by the ECtHR addresses situations of under-inclusiveness: a social benefit (the distribution of which is not mandatory under the ECHR) is granted to some, but certain other individuals are excluded in a discriminatory fashion. ${ }^{138}$ For example, if the state provides for free university education, it may not discriminate, regarding access to the university, on the basis of gender or national origin of the student.

Nonetheless, despite the judicial extension, the ancillary design of Article 14 ECHR has, in the past, prevented a progressive interpretation of that provision with the result that the ECtHR often eschews applying the non-discrimination clause and decides the case under the head of substantive rights only. The reinterpretation of discrimination issues as civil rights problems tends to conceal the discriminatory injustice in some alarming cases. ${ }^{139}$ It is likely to act as a brake on the judicial treatment of the issues of socioeconomic inequality, too.

In contrast to equal protection clauses, non-discrimination norms (for example, Article 2(2) ICESCR, Article 14 ECHR) require the relevant treatment to be based on a ground of discrimination. While, usually, the listed grounds of discrimination (such as gender, religion) are not exhaustive (explicitly mentioning 'other status'), socioeconomic status or poverty are rarely, if ever, accepted as an unwritten ground. However, both Article 2(2) ICESCR and Articles 14 and 1 Protocol 12 ECHR include 'social origin' and 'property' among the enumerated grounds of discrimination, and - importantly - Article 1(1) ACHR explicitly lists the 'economic status' of a person. ${ }^{140}$ The question is whether these grounds constitute 'social class-related' discrimination criteria which would allow for problems of socioeconomic inequality to be brought within the scope of the prohibition of discrimination. ${ }^{141}$ In the case law of the CESCR, there is no reference at all to the ground of social origin, and it has so far played only a marginal role in the decision-

\footnotetext{
${ }^{134}$ See Altwicker, supra note 21, at 497.

${ }^{135}$ ECtHR, Molla Sali v. Greece, Appl. no. 20452/14, Judgment of 19 December 2018, para. 123.

${ }^{136} \mathrm{ECtHR}$, Yeshtla v. the Netherlands, Appl. no. 37115/11, Decision of 15 January 2019, para. 33 (stating that 'neither Article 8 nor any other provision of the Convention guarantees, as such, a right to social security benefits or any social benefit of a particular amount, and does not confer on an individual a right to enjoy any given standard of living'). See Leijten, supra note 89 , at $47-58$.

${ }^{137}$ ECtHR, Stec and others v. United Kingdom, Appl. no. 65731/01, Judgment of 12 April 2006, para. 53.

${ }^{138}$ L. Lavrysen, 'Poverty and Human Rights: A European Perspective', in E. Brems, C. van der Beken and S. Yimer (eds.), Human Rights and Development (2015), 301, at 315.

${ }^{139}$ See Altwicker, supra note 21 , at 138 with further references.

${ }^{140}$ IACtHR, Exceptions to the Exhaustion of Domestic Remedies (Arts. 46(1), 46(2)(a) and 46(2)(b), American Convention on Human Rights), Advisory Opinion OC-11/90 of August 10, 1990, Series A No. 11, para. 22; IACtHR, Case of the Hacienda Brasil Verde Workers v. Brazil, Preliminary Objections, Merits, Reparations and Costs, Judgment of 20 October 2016, Series C No. 318, paras. 339-341.

${ }^{141}$ On the concept of 'social class' see L. Warwick-Booth, Social Inequality (2019), at 27-53. For the human rights context see T. Altwicker, 'Sozio-ökonomische Ungleichheit und konventionsrechtliche Diskriminierungsverbote', (2019) Juridikum 237 , at 242 .
} 
making of the ECtHR. ${ }^{142}$ This may be due to the vagueness of the term. ${ }^{143}$ It is questionable whether the ground of social origin can be interpreted in a social class-related sense. In a General Comment, the CESCR referred to social origin as the 'inherited social status of a person'.

Similarly, in another interpretation, social origin references the 'descent ... of human beings ... especially the social position of their ancestors'. ${ }^{144}$ However, there are hardly any cases conceivable where the state would attach adverse legal consequences to the social origin in this narrowly construed sense. Others have advocated a somewhat broader definition: in their view, social origin refers to the 'status imputed to an individual by virtue of an inherited social, economic or biological feature. ${ }^{145}$ The ECtHR, too, seems to favour a narrow interpretation of the social origin in connection with the explicitly mentioned discrimination ground of 'birth'. In the Stjerna case, for example, the applicant was not allowed to take the name of an ancestor who had died more than 200 years ago. ${ }^{146}$ The applicant considered that his social origin was adversely affected because one of his ancestors came from an illegitimate relationship. However, since this was irrelevant to the authorities' refusal to change the name, the ECtHR did not pick up on this matter. In another case, Dempsey, the socioeconomic component was more apparent. ${ }^{147}$ In this case, the applicant complained of unequal treatment for free legal assistance in an adoption dispute. According to the applicant (the biological mother), the alleged discrimination was that the comparatively more prosperous, prospective adoptive parents had access to free legal assistance more quickly than her. ${ }^{148}$ For lack of substantiation, the ECtHR did not deal with this complaint. So far, thus, any complaint before the ECtHR based on the discrimination ground of 'social origin' has been unsuccessful. ${ }^{149}$ In this situation, it seems unlikely that the ECtHR would be willing to give an extensive interpretation to the discrimination ground of 'social origin'.

The other discrimination ground - enumerated in both Article 2(2) ICESCR and Article14, Article 1 Protocol 12 ECHR - that could, potentially, encompass a socioeconomic dimension is that of 'property' (in French 'la fortune'). ${ }^{150}$ It can be interpreted as one's status in relation to movable or immovable assets (for example, being a tenant, owner, or illegal occupant). ${ }^{151}$ Neither the CESCR nor the ECtHR has made much use of this discrimination ground so far. The former European Commission of Human Rights (ECommHR) had to assess the case of H.S. and D.M., which concerned, inter alia, the question of whether the absence of free administration of justice and a cap on claims for damages constituted a violation of the prohibition of discrimination on the basis of property. ${ }^{152}$ In this case, the ECommHR acknowledged that, although wealthy persons are in principle better able to defend their rights in most circumstances, the states had a margin of appreciation in the organization of the free administration of justice. This margin also allowed for the exclusion of certain objects of litigation (such as in the present case, an action concerning libel) from the scope of free administration of justice. ${ }^{153}$ In the case of Chassagnou, the ECtHR found a violation of the prohibition of discrimination on the basis of

\footnotetext{
${ }^{142} \mathrm{~A}$ search on the CESCR database no entries on discrimination on the ground of 'social origin' or 'property' (2 April 2020). Under the ECHR, roughly three cases explicitly deal with 'social origin' (see text).

${ }^{143}$ See, for a different context, Explanatory Report to the European Convention on Nationality, 6 November 1997, ETS No. $166, \S 43$.

${ }^{144}$ See, for the European Charter of Fundamental Rights, S. Hölscheidt, 'Art. 21', in F. Meyer (ed.), Charta der Grundrechte der Europäischen Union (2014), at para. 44 [translation by the author].

${ }^{145}$ European Union Agency for Fundamental Rights and Council of Europe, Handbook on European Non-Discrimination Law (2018), at 218.

${ }^{146}$ ECtHR, Stjerna v. Finland, Appl. no. 18131/91, Judgment of 25 November 1994.

${ }^{147}$ ECtHR, Dempsey v. Ireland, Appl. no. 41382/98, Judgment of 6 April 2000.

${ }^{148}$ Ibid., para. 2.

${ }^{149}$ ECtHR, Truta v. Roumania, 31 August 2010, Appl. no. 20121/04, para 45.

${ }^{150}$ See Altwicker, supra note 141 , at 243-5.

${ }^{151}$ See European Union Agency for Fundamental Rights and Council of Europe, supra note 148, at 218.

${ }^{152}$ ECommHR, H.S. and D.M. v. the United Kingdom, Appl. no. 21325/93, Decision of 5 May 1993, para. 3.

${ }^{153}$ Ibid.
} 
property: the case concerned the obligation of owners of small plots of land to become members of a hunting co-operative, whereas this obligation did not apply to owners of large plots of land. ${ }^{154}$ In other cases, the ECtHR rejected claims based on that discrimination ground as not sufficiently substantiated. ${ }^{155}$

In sum, currently, only Article 1(1) ACHR explicitly lists a person's 'economic status.' Under both the ICESCR and the ECHR, such ground is missing. In addition, both the - at least potentially - social class-related grounds of discrimination (social origin, property) have not yet played a role in the caselaw of the CESCR or the ECtHR. If they were referred to at all, a narrow interpretation was followed. Importantly thus, neither the ICESCR nor the ECHR, so far, captured the group of the 'poor' or 'socially disadvantaged' by the discrimination grounds of social origin or property.

\subsubsection{Socioeconomic discrimination by effect}

Instances of direct socioeconomic discrimination - that is, the unequal distribution of socioeconomic goods explicitly based on the traditional discrimination grounds of gender, sexual orientation, national origin, etc. - are rare. ${ }^{156}$ Rather, socioeconomic inequality often arises indirectly from the discriminatory effects of general norms or discriminatory institutional structures. Under IEPL, this is called indirect discrimination or disparate impact. ${ }^{157}$ This is the case when applying a statutory law, or general administrative measure disproportionally and adversely affects the poor or the socioeconomically less well-off. To give an example: there are reports that the closure of schools, a general measure during the SARS-CoV-2 Pandemic, has led to a disproportionate disadvantage for poor children as their families do not have the financial means to adequately compensate for the lack of in-person teaching (by hiring online tutors, by providing for the technical equipment required for online tuition, etc.). ${ }^{158}$ Over the last two decades, IEPL came to embrace more fully the concept of indirect discrimination, and it is today conceptually recognized by all international human rights bodies under consideration here. ${ }^{159}$ The leading case on indirect discrimination by the ECtHR is D.H. and others concerning the disproportionately large number of Roma children in 'special schools'. ${ }^{160}$ In this case, the ECtHR defined indirect discrimination as a difference in treatment that takes 'the form of disproportionately prejudicial effects of a general policy or measure which, though couched in neutral terms, discriminates against a group'. ${ }^{161}$ Indirect discrimination does not require a discriminatory intent, and its prima facie presence in a particular case can be proven through the use of statistical evidence. ${ }^{162}$

When applying the concept of indirect discrimination to the distribution of socioeconomic goods, two scenarios must be distinguished. In the first scenario, a general measure or policy has disproportional prejudicial effects on the access or availability of socioeconomic goods for a protected group identifiable by the accepted grounds of discrimination (such as gender or nationality). This was, for example, the case in Di Trizio, where the ECtHR found that the method

\footnotetext{
${ }^{154}$ ECtHR, Chassagnou et al. v. France, Appl. no. 25088/94, Judgment of 29 April 1999, paras 118-121.

${ }^{155}$ ECtHR, Pawlow v. Finland, Appl. no. 53434/99, Judgment of 14 February 2006.

${ }^{156}$ See, for an example, ECtHR, Konstantin Markin v. Russia, Appl. no. 30078/06, Judgment of 22 March 2012, para. 152.

${ }^{157}$ See Altwicker, supra note 21, at 266-303.

${ }^{158}$ A. Vesoulis, 'How Coronavirus Will Hurt the Poor', Time Magazine, 11 March 2020, available at time.com/5800930/ how-coronavirus-will-hurt-the-poor/.

${ }^{159}$ HRC, Sonia Yaker v. France, No. 2747/2016, 7 December 2018, CCPR/C/123/D/2747/2016, para. 8.14; CESCR, Trujillo Calero v. Ecuador, No. 10/2015, 26 March 2018, E/C.12/63/D/10/2015, para. 13.12; General Comment No. 20, NonDiscrimination in Economic, Social and Cultural Rights (Art. 2, para. 2) UN Doc. E/C.12/GC/20 (2009), \$ 10(b); IACtHR, The Yean and Bosico Children v. Dominican Republic, Judgment of 8 September 2005, Series C No. 130 (2005), para. 141; ECtHR, D.H. and Others v. Czech Republic, Appl. no. 57325/00, Judgment of 13 November 2007, paras 184-195.

${ }^{160} \mathrm{ECtHR}$, D.H. and Others v. Czech Republic, ibid.

${ }^{161}$ Ibid., para. 175.

${ }^{162}$ Ibid., paras. 184, 187-193.
} 
of calculating invalidity benefits, a socioeconomic good, constituted indirect discrimination against women in Switzerland. ${ }^{163}$ In the second scenario, the discriminatory effects pertain to a group identifiable by the socioeconomic status of its members ('the poor'). So far, the ECtHR has not explicitly dealt with the second scenario. The second scenario arguably played a role in the case of Mellet, decided by the HRC concerning the disparate socioeconomic impact of the general abortion ban in Ireland: pregnant women with little financial means were found to be more heavily affected by having to travel abroad for abortion than more affluent women. ${ }^{164}$ While the first scenario (indirect socioeconomic discrimination of a protected group) falls under the accepted doctrine, the second scenario (indirect discrimination of a group identifiable by the socioeconomic status of its members) poses intricate doctrinal problems. The first problem concerns identifying a group that can be referred to as 'the poor'. While it is common to identify the group of 'the poor' based on income thresholds within societies, the details of measuring poverty and delineating the group of the haves from the have-nots is complex. ${ }^{165}$ An IHR court that needs to engage with the econometric method of measuring poverty in society to decide a case may easily be overburdened. ${ }^{166} \mathrm{~A}$ second problem concerns the justification of discriminatory effects on the group of the poor. What are the legitimate aims that justify discriminatory effects of a general measure or policy on the group of the poor? As outlined above, the philosopher John Rawls argued that socioeconomic inequalities were only permissible in his Theory of Justice if the group of the least-well off in society derived some form of benefit from the unequal distribution. ${ }^{167}$ In reality, an empirical assessment of the Rawlsian condition of distributive fairness seems impossible to make. Instead, courts will have to rely on the commonly accepted legitimate aims such as protecting the rights and freedom of others. ${ }^{168} \mathrm{~A}$ wide margin of appreciation is to be expected in these cases. It should be noted that, presently, the second scenario is an academic problem: as explained above, except for the IACtHR, the group of 'the poor' is currently not viewed by international human rights bodies as constituting a protected group of persons under IEPL. At present, only cases in which the measure disproportionately burdens poor persons who also belong to a group of persons protected for another reason (e.g., the group of Roma, single mothers) are covered.

\subsubsection{Positive obligation to provide for socioeconomic goods}

Does IEPL entail positive obligations aimed at the fair distribution of socioeconomic goods? In general, under IHRL, it is accepted that positive obligations may not only follow from civil liberties but also from equal protection. ${ }^{169}$ In particular, as the following discussion shows, some international human rights bodies have started to acknowledge IEPL-based positive obligations to provide for socioeconomic goods (duty to fulfil). ${ }^{170}$ Again, two scenarios need to be distinguished here.

First, there is an IEPL-based positive obligation to provide for socioeconomic goods, available within an existing scheme, in a non-discriminatory manner. ${ }^{171}$ As mentioned above, international

\footnotetext{
${ }^{163}$ ECtHR, Di Trizio v. Switzerland, Appl. no. 7186/09, Judgment of 2 February 2016.

${ }^{164} \mathrm{HRC}$, Amanda Jane Mellet v. Ireland, 17 November 2016, CCPR/C/116/D/2324/2013, para. 7.10

${ }^{165}$ S. Alkire and M. E. Santos, 'Acute Multidimensional Poverty: A New Index for Developing Countries', Human Development Research Paper 2010/11, 2010, available at hdr.undp.org/sites/default/files/hdrp_2010_11.pdf.

${ }^{166}$ See below Section 3.3.

${ }^{167}$ See above Section 2.1 .

${ }^{168}$ See, for example, Art. 8 ECHR.

${ }^{169}$ For the ICCPR see Nowak, Art. 26 ICCPR, in M. Nowak (ed.), UN Covenant on Civil and Political Rights, CCPR Commentary (2019), at paras. 53 et seq. For the ECHR see Altwicker, supra note 21, at 314-96.

${ }^{170} \mathrm{~A}$ quite far-ranging positive obligation is suggested in CESCR, General comment No. 24 (2017) on State obligations under the International Covenant on Economic, Social and Cultural Rights in the context of business activities, 10 August 2017, UN Doc. E/C.12/GC/24, $\$ 7$ ('stipulating a duty to prohibit discrimination by non-State entities in the exercise of economic, social and cultural rights').

171'Availability within the existing schemes' means that IHRL does not give rise to a right directed at setting up new schemes for the provision of socioeconomic goods. Any claim to these goods is thus limited by the existing quota.
} 
human rights bodies have extended this obligation to those goods and services the state has voluntarily decided to provide. ${ }^{172}$ For example, in Waldman, a case concerning differences in the financial support for Roman Catholic and Jewish private schools, the HRC held that 'the Covenant does not oblige States parties to fund schools which are established on a religious basis. However, if a State party chooses to provide public funding to religious schools, it should make this funding available without discrimination'. ${ }^{173}$ Similarly, although the ECHR does not give rise to a right to social security benefits of any kind, the ECtHR has consistently held that if a State does decide to create a benefits scheme, it must do so in a manner which is compatible with Article 14'. ${ }^{174}$ The ECtHR has applied this line of reasoning regarding family allowances, ${ }^{175}$ parental/ maternity leave schemes, ${ }^{176}$ old-age pensions, ${ }^{177}$ the apportioning of a survivor's pension, etc. ${ }^{178}$ In all of these cases, what is claimed is fair (equal) access to socioeconomic goods. The fairness problem in this first scenario is one of formal equality: some members of society are excluded from the enjoyment of socioeconomic goods, although there are no relevant differences between the 'included' (recipients) and the 'excluded' (claimants). If there are no relevant differences, the principle of formal equality demands equal (identical or neutral) treatment. ${ }^{179}$ An intriguing, unsolved question relates to the legal consequences resulting from a finding of a violation in these cases: in this situation, the problem of 'levelling down' arises when the state, in response to the international judgment, seeks to abolish the social benefit altogether (with the result that everyone is treated equally). In the recent case of Khamtokhu and Aksenchik, the ECtHR upheld a provision in Russian penal law differentiating in respect of life-long imprisonment between men and women: women, but not men, were exempted from life-long imprisonment. ${ }^{180}$ In this situation, if the ECtHR had voted for the contrary and found Russia in violation of Article 14 ECHR, Russia could have implemented the judgment either by extending the privilege to men or by abolishing the privilege altogether. In her concurring opinion, Judge Nussberger argued that '[i]t would be appalling if such a backward step were justified by the necessity to execute a judgment of the Court and were even done under the supervision of the Committee of Ministers'. ${ }^{181}$ Similarly, Judge Albuquerque argued that 'levelling down' is impermissible. ${ }^{182}$

In recent years, a second scenario involving IEPL-based positive obligations to provide for socioeconomic goods has gained ground within international human rights bodies. This is not about equal access but about preferential access to socioeconomic goods. In essence, preferential access to socioeconomic goods entails two positive obligations: (i) a positive obligation to provide certain individuals with socioeconomic goods, and (ii) to introduce measures designed to ensure that underprivileged individuals have a real chance to gradually achieve material equality with the majority society. Both obligations concern substantive equality: some members of society may demand privileged access to socioeconomic goods due to the existence of legally relevant differences between them and the majority. While the positive obligation to create new opportunities

\footnotetext{
${ }^{172}$ ECtHR, Stec and others v. United Kingdom, Appl. no. 65731/01, Judgment of 12 April 2006, para. 53.

${ }^{173}$ HRC, Waldman v. Canada, No. 694/1996, Communication of 5 November 1999, UN Doc. CCPR/C/67/D/694/1996 (1999), $\$ 10.6$.

${ }^{174} \mathrm{ECtHR}$, Stec and Others v. United Kingdom, Appl. no. 65731/01 et al., Decision of 6 July 2005, para. 55.

${ }^{175}$ ECtHR, Efe v. Austria, Appl. no. 9134/06, Judgment of 8 January 2013, para. 45.

${ }^{176}$ ECtHR, Konstantin Markin v. Russia, Appl. no. 30078/06, 22 March 2012, para. 130.

${ }^{177}$ ECtHR, Fábián v. Hungary, Appl. no. 78117/13, Judgment of 5 September 2017, para. 117.

${ }^{178}$ ECtHR, Ruszkowska v. Poland, Appl. no. 6717/08, Judgment of 1 July 2014, para. 54.

${ }^{179}$ This is sometimes called the 'Aristotle'-principle, see Aristotle, Nicomachean Ethics (1926), V.6, 1131a10-b15, 267; CESCR, General comment no. 16 (2005), The equal right of men and women to the enjoyment of all economic, social and cultural rights, 11 August 2005, UN Doc. E/C.12/2005/4, para. 7.

${ }^{180}$ ECtHR, Khamtokhu and Aksenchik v. Russia, Appl. no. 60367/08 et al., Judgment of 24 January 2017.

${ }^{181}$ Conc. op. Nussberger in ECtHR, Khamtokhu and Aksenchik v. Russia, Appl. no. 60367/08 et al., Judgment of 24 January 2017, para. 7.

${ }^{182}$ Dissenting opinion Albuquerque in ECtHR, Khamtokhu and Aksenchik v. Russia, Appl. no. 60367/08 et al., Judgment of 24 January 2017, para. 23 (pointing to the objectives of the ECHR as emerging from its preamble).
} 
for the realization of material equality for the underprivileged in society is primarily directed at the legislator, the obligation to provide certain individuals with socioeconomic goods concerns the executive. The positive obligation to preferential access to socioeconomic goods reflects an asymmetrical approach to equality. According to a famous formula coined by Ronald Dworkin, substantive equality means 'treatment as an equal'. ${ }^{183}$ Essentially, this reflects the human dignitybased moral claim that everyone is to be treated with the same respect. ${ }^{184}$ Translated to the legal context, the principle of substantive equality can justify positive obligations relating to the differential or even preferential treatment of individuals in order to ensure an equality of result. ${ }^{185} \mathrm{In}$ recent times, the principle of substantive equality has gradually found its way into the reasoning of international human rights bodies. It has been invoked, for example, by the CESCR in the context of obligations to remove existing disadvantages women experience in exercising their right to sexual and reproductive health.

The ECtHR has made a brief reference to the principle of substantive equality in gender-discrimination cases. ${ }^{186}$ More often, however, the principle of substantive equality is more implicit in the ECtHR's reasoning, manifesting itself in the following formula: in certain circumstances, a failure to attempt to correct inequality through different treatment may in itself give rise to a breach of Article 14. ${ }^{187}$ Similarly, without explicitly invoking it, the IACtHR has relied on the principle in several cases. ${ }^{188}$ In the recent Fireworks Factory case, the IACtHR significantly broadened the application of substantive equality. ${ }^{189}$ The case concerned Brazil's responsibility for events relating to an explosion in a fireworks factory that led to the death of 60 people. Relying on the right to equal protection (Article $24 \mathrm{ACHR}$ ), the IACtHR held that the right to equality:

entails the obligation to adopt measures that ensure that the equality is real and effective; in other words, to correct existing inequalities, to promote the inclusion and participation of historically marginalized groups, and to guarantee to disadvantaged individuals or groups the effective enjoyment of their rights and, in short, to provide individuals with the real possibility of achieving material equality. To this end, States must actively combat situations of exclusion and marginalization. ${ }^{190}$

In the present case, Brazil had discriminated against the factory workers because they remained in a 'situation of structural poverty', and the state had failed to set up governmental programs to reverse that situation. ${ }^{191}$ In essence, in the Fireworks Factory case, the IACtHR articulated an international right to substantive equality unrelated to existing domestic poverty reduction schemes, that is, an obligation to create new poverty reduction schemes in situations of continued social exclusion and marginalization resulting from structural discrimination. ${ }^{192}$ This reflects a

\footnotetext{
${ }^{183}$ R. Dworkin, Taking Rights Seriously (1977), at 227.

${ }^{184}$ Ibid., at $180-3$.

${ }^{185}$ CESCR, General comment no. 16 (2005), The equal right of men and women to the enjoyment of all economic, social and cultural rights, 11 August 2005, UN Doc. E/C.12/2005/4, \$ 7; CRPD, General comment No. 6 (2018) on equality and nondiscrimination, 26 April 2018, UN Doc. CRPD/C/GC/6, $\$ 10$.

${ }^{186}$ See, for example, ECtHR, Volodina v. Russia, Appl. no. 41261/17, Judgment of 9 July 2019, para. 111 ('substantive gender equality').

${ }^{187}$ ECtHR, D.H. and Others v. Czech Republic, Appl. no. 57325/00, Judgment of 13 November 2007, para. 175.

${ }^{188}$ See IACtHR, Furlan and Family v. Argentina, Judgment of 31 August 2012, para. 267.

${ }^{189} \mathrm{IACtHR}$, Case of the Workers of the Fireworks Factory in Santo Antônio de Jesus and their families v. Brazil, Judgment of 15 July 2020.

${ }^{190}$ Ibid., para. 199.

${ }^{191}$ Ibid., para. 200.

${ }^{192}$ For an assessment see A. T. Saliba and M. F. Vallandro do Valle, 'The Inter-American Court of Human Rights and the Quest for Equality: The Fireworks Factory Case', EJIL Talk!, 20 January 2021, available at www.ejiltalk.org/the-inter-americancourt-of-human-rights-and-the-quest-for-equality-the-fireworks-factory-case/.
} 
very progressive judicial stance on a controversial issue and thus evidences the transformative potential of socioeconomic equality as a human right.

The principle of substantive equality is also brought to bear in the context of preferential access to socioeconomic goods. ${ }^{193}$ In a striking similarity of the legal argument, international human rights bodies have based positive obligations concerning preferential access to socioeconomic goods on a conception of vulnerability in recent years. This approach has its roots in the 1993 Vienna Declaration and Programme of Action. ${ }^{194}$ With differences in the details, vulnerable groups may include ethnic minorities and indigenous populations, women, children, adolescents, older persons, persons with disabilities, persons with HIV/AIDS, etc. ${ }^{195}$ The ECtHR has acknowledged four categories of vulnerable groups: the Roma minority, mentally disabled persons, asylum seekers, and people living with HIV. ${ }^{196}$ For example, in the case of Horváth and Kiss, the ECtHR held that the 'Roma have become a specific type of disadvantaged and vulnerable minority' requiring special protection. ${ }^{197}$ The ECtHR found that Hungary violated Article 2 Protocol 1 (right to education) in conjunction with Article 14 ECHR (prohibition of discrimination) because the Roma applicants had not received an education in line with 'the positive obligations of the State to undo a history of racial segregation in special schools'. ${ }^{198}$ Unfortunately, the ECtHR is not consistent in its approach to vulnerability-based preferential access to socioeconomic goods. In the case of Yordanova and Others, while acknowledging a positive obligation to provide preferential treatment for housing based on the 'disadvantaged position of a social group', the ECtHR failed to address this as a non-discrimination problem. ${ }^{199}$ Other IHR bodies have made similar use of a vulnerability conception as a basis for positive, socioeconomic claims: in a case concerning the authorities' failure to acknowledge the vulnerability of the claimant as a minor and member of an ethnic minority group in a rape allegations case, the HRC found the contracting state to have violated, among other things, the positive obligation to provide reparation under the equal treatment clause (Article 26 ICCPR). ${ }^{200}$

In sum, IEPL contains positive obligations aimed at the fair distribution of socioeconomic goods. The principle of formal equality demands equal access to socioeconomic benefits if there are no legitimate differences between the recipients and the claimants. The HRC and the ECtHR have acknowledged the positive obligation to extend existing socioeconomic benefits in these cases. A more recent development of positive obligations within the field of socioeconomic benefits revolves around the notion of vulnerability. A conception of substantive equality is brought to bear to argue that members of vulnerable groups (for example, the Roma), in some cases, have a right to preferential access to socioeconomic benefits.

\footnotetext{
${ }^{193}$ In its recent General Comment No. 18, the CRPD introduced an 'inclusive model' of equality which includes 'a fair redistributive dimension to address socioeconomic disadvantages' (among other things), CRPD, General comment No. 6 (2018) on equality and non-discrimination, 26 April 2018, UN Doc. CRPD/C/GC/6, para. 11.

${ }^{194}$ World Conference on Human Rights, Vienna Declaration and Programme of Action, 25 June 1993, UN Doc. A/ CONF.157/23, \$24; I. Nifosi-Sutton, The Protection of Vulnerable Groups under International Human Rights Law (2017).

${ }^{195}$ See for this list CESCR, General Comment No. 14: The Right to the Highest Attainable Standard of Health (Art. 12), 11 August 2000, UN Doc. E/C.12/2000/4, para. 12.b.

${ }^{196} \mathrm{M}$. Bossuyt, 'Categorical Rights and Vulnerable Groups: Moving Away from the Universal Human Being', (2016) 48 George Washington International Law Review 717, at 726-9.

${ }^{197}$ ECtHR, Horváth and Kiss v. Hungary, Appl. no. 11146/11, Judgment of 29 January 2013, para 102.

${ }^{198}$ Ibid., para. 127.

${ }^{199}$ ECtHR, Yordanova and Others v. Bulgaria, Appl. no. 25446/06, Judgment of 24 April 2012, paras. 130-134; 145-149. For related criticism see Peroni and Timmer, 'Vulnerable Groups: The Promise of an Emerging Concept in European Human Rights Convention Law', (2013) 11 ICON 1056, at 1068.

${ }^{200}$ HRC, X. v. Sri Lanka, Communication of 27 July 2017, UN Doc. CCPR/C/120/D/2256/2013, para. 7.6.
} 


\subsection{Institutional legitimacy of international socioeconomic equality adjudication}

Empowering the international judiciary to tackle issues of domestic socioeconomic equality means an increase of international judicial power. This creates problems of institutional legitimacy often captured as 'the right to rule'. ${ }^{201}$ Should international human rights bodies have the right to rule on domestic socioeconomic equality?

A first possible objection is that the international judiciary lacks the expertise to adjudicate complex problems of socioeconomic inequality, e.g., how to identify the relevant inequalities in the first place. More than many other human rights, the adjudication of a right to socioeconomic equality would require an intricate factual analysis as these disputes always revolve around the problem that someone has 'less' of a socioeconomic good than another. How to measure and how to evaluate the relevant inequalities is highly controversial. ${ }^{202}$ Human rights courts and commissions will often have to rely on statistics to prove, for example, the disparate impact of a general measure. In recent years, IHR bodies have become more open to statistics-based legal arguments, especially in the context of IEPL. The utility of statistical data in international human rights contexts was first emphasized already in the late 1980s. ${ }^{203}$ Relatedly, the 2006 CRPD establishes an explicit legal obligation to collect statistical data. ${ }^{204}$ In the context of non-discrimination, the ECtHR has accepted the use of statistics since its landmark judgment in D.H v. Czech Republic, in which it allowed statistical data to prove a prima facie indirect discrimination. ${ }^{205}$ Recently, in the case of Di Trizio, the ECtHR found the statistical data presented to be sufficiently reliable and significant (in a non-statistical sense) to disclose a prima facie indirect discrimination of women. ${ }^{206}$ Furthermore, the ECtHR is already familiar with reviewing domestic impact assessments (for example, on environmental issues). ${ }^{207}$ It can be argued, thus, that - given the growing importance of statistics in IHRL - the lack of expertise objection is losing weight.

The second objection - the democracy objection - is more difficult to refute. This objection essentially asserts that socioeconomic inequalities are for the domestic legislator to resolve, not for the international judiciary. The reason is that this policy area must be open to experimental legislation, that it is often characterized by the absence of consensus among states, and that it must be possible for states, given the scarcity of resources, to pursue their political preferences emerging from a domestic democratic consensus. ${ }^{208}$ The democracy objection resonates well with the principle of subsidiarity and the idea that the national legislator is, in general, better placed to assess the needs of the people. Nonetheless, two peculiarities of socioeconomic inequalities suggest a role for international adjudication: first, international review allows for an external audit; it is a review 'from the outside'. This may be especially beneficial given that socioeconomic inequality is often both a cause and consequence of systemic discrimination, as could be seen in the Brazilian

\footnotetext{
${ }^{201}$ A. Buchanan and R. O. Keohane, 'The Legitimacy of Global Governance Institutions', (2006) 20 Ethics and International Affairs 405.

${ }^{202}$ See Milanovic, supra note 1 , at $46-117$.

${ }^{203}$ In 1989, the CEDAW Committee noted 'that statistical information is absolutely necessary in order to understand the real situation of women in each of the States parties to the Convention', CEDAW Committee, General Recommendation No. 9, 1989.

${ }^{204}$ Art. 31 CRPD.

${ }^{205}$ ECtHR, D.H. and others v. Czech Republic, Appl. no. 58641/00, Judgment of 13 November 2007, paras. 180, 188; ECtHR, M.S.S. v. Belgium and Greece, Appl. no. 30696/09, Judgment of 21 January 2011, paras. 126, 313; ECtHR, Volodina v. Russia, Appl. no. 41261/17, Judgment of 9 July 2019, paras. 112-126.

${ }^{206}$ ECtHR, Di Trizio, supra note 163, paras. 88-90.

${ }^{207}$ See, for example, ECtHR, Unite the Union v. United Kingdom, Appl. no. 65397/13, Decision of 3 May 2016, para. 64 (collective bargaining); ECtHR, Communicated Case, Appl. no. 52499/11, 8 October 2014 (environmental impact assessment).

${ }^{208}$ See, for a treatment of some of these arguments, ECtHR, Hudorovič and others v. Slovenia, Appl. no. 24816/14 et al., Judgment of 10 March 2020, para. 141. See also the call for more judicial restraint in the separate opionion of Judges Wojtyczek and Pejchal in ECtHR, J.D. and A. v. United Kingdom, Appl. no. 32949/17 et al., Judgment of 24 October 2019 (' $[\mathrm{T}]$ he judge and in particular the European judge, has to be extremely cautious in exercising his or her discretion in equality and discrimination cases, especially if their gist lies in an allegedly deficient allocation of financial resources').
} 
Fireworks Factory case. Pervasive discrimination against members of marginalized groups in society leads to greater socioeconomic inequality; this, in turn, fosters further marginalization and discrimination. ${ }^{209}$ Systemic equality means that its roots date back far in history, it is - to a certain extent - entrenched in the institutions, and it often goes unchallenged in the domestic courts. ${ }^{210}$ As outsiders, international judges may be better placed to identify entrenched, structural forms of discrimination. Second, if the distribution of socioeconomic goods within a society will, in the future, be increasingly determined by (informal or formal) rules construed beyond that society, on an international level, it makes sense to establish an international review of the socioeconomic impact of these rules.

In addition, the democracy objection can be alleviated somewhat. Traditionally, some international human rights bodies grant the states a wide margin of appreciation in matters of socioeconomic policy. ${ }^{211}$ Therefore, if abstract-general domestic measures are concerned, the ECtHR has started to shift its focus from a substantive review (reviewing the legislative choice directly against the law of the ECHR) to a procedural review of these measures (reviewing the process that led to the adoption of a law and its defence in domestic courts). ${ }^{212}$ In other words, the international judge reviews the fairness of the process leading to a domestic rule or decision (but not the substance of the measure itself). In this respect, starting with the case of Animal Defenders International, the ECtHR has stressed that the 'quality of the parliamentary and judicial review of the necessity of the measure is of particular importance'. ${ }^{213}$ In Garib, the case most directly engaging with the problem of socioeconomic equality, the Chamber analysed the legislative process in some detail and found that it is not for the Court to say whether the measure complained of represented the best solution for dealing with the problem or whether the State's discretion should have been exercised in another way'. ${ }^{214}$ In principle, the procedural review of abstract-general measures impacting socioeconomic equality appears a commendable first step to integrating socioeconomic inequality into the adjudication of IHRL by international courts. ${ }^{215}$

\section{Conclusion: The social is the new liberal}

The philosopher John Rawls argued that it seems wrong that some or much of society should be amply provided for, while many, or even a few, suffer hardship, not to mention hunger and treatable illness' ${ }^{216}$ Therefore, the present article examines the role of IHRL in addressing the inequality between the haves and the have-nots in society. Presently, IEPL can offer only a limited response to pressing demands of social justice and, in particular, socioeconomic equality. Under current IEPL, socioeconomic inequalities have become a human rights issue in two quite restricted scenarios. First, in the situation of under-inclusiveness (some individuals are excluded from a social benefit based on a discrimination ground). Second, in cases concerning members of vulnerable groups (special needs of people belonging to a historically disadvantaged group). ${ }^{217}$ In the first scenario, it is the principle of formal equality, and in the second, the idea of social exclusion and marginalization triggers protection by IEPL. Most importantly, only under the ACHR is

\footnotetext{
${ }^{209}$ See CERD supra note 117; ECRI supra note 128.

${ }^{210}$ See CESCR, General Comment No. 20, 2 July 2009, UN Doc. E/C.12/GC/20, $\$ \$ 1,12$.

${ }^{211}$ See the references supra note 80 .

${ }^{212}$ O. M. Arnardóttir, "The "procedural turn" under the European Convention on Human Rights and presumptions of Convention compliance', (2017) 15 ICON 9; T. Kleinlein, 'Consensus and Contestability: The ECtHR and the Combined Potential of European Consensus and Procedural Rationality Control', (2017) 28 EJIL 871, at 879.

${ }^{213}$ ECtHR, Animal Defenders International v. United Kingdom, Appl. no. 48876/08, Judgment of 22 April 2013, para. 108.

${ }^{214}$ ECtHR, Garib v. Netherlands, Appl. no. 43494/09, Judgment of 23 February 2016, paras. 118-136.

${ }^{215}$ It may be objected that the de facto socioeconomic inequality prevailing in a state may itself be regarded as a factor relevant in the assessment of the procedural fairness. I am grateful to Hurst Hannum for this point.

${ }^{216}$ See Rawls, supra note 61, 130.

${ }^{217}$ See Section 3.2.
} 
the socioeconomic status ('being poorer than other members of society') a protected ground of discrimination.

This article shows that integrating socioeconomic equality into the international human rights agenda is deeply transformative both doctrinally and concerning the international adjudication of rights. Arguably the greatest doctrinal transformation relates to the issue of positive obligations: should IHRL be interpreted to include a right to preferential access to socioeconomic goods outside existing domestic provision schemes? Relatedly, the institutional transformation reverberates around this problem: should international human rights courts be empowered to evaluate domestic rules and regulations on their conformity with international socioeconomic equality standards?

What are the chances that socioeconomic equality will be added more fully to the international human rights agenda? While it may appear as a bold step, some recent developments in IHRL are likely to amplify a trend that may eventually make the social the new liberal. Just as civil and political rights have had a rationalizing effect on various areas of public policy, bringing socioeconomic inequalities within the range of IHRL would have a rationalizing effect on affairs of social justice: it would put certain arguments to the test (e.g., that the unemployment-status of a person may serve as an argument to withhold a residence permit, as in the case of Garib). Current developments exacerbate this rationalizing trend. First, empirical research is likely to reveal the discriminatory socioeconomic impact of accepted practices in our societies, subjecting these rules and practices to ever closer scrutiny. Second, a further increase of the transborder mobility of labour, income, and capital in a globalized world will exacerbate the new transnational social question, making a legal response ever more likely. Third, a moral view that some extreme socioeconomic inequalities are unacceptable and need correction is gaining ground transnationally. An example is a state denying an individual lacking the financial means access to life-supporting medicine. ${ }^{218}$

It is a question of time until these arguments will be adopted in the judicial interpretation of IHRL, and IEPL in particular. The more the conditions and dependencies of concrete individual freedom are uncovered, the more will the social become the new liberal and eventually inspire a new international human rights agenda.

${ }^{218}$ See Lavrysen, supra note 138 , at $307-8$.

Cite this article: Altwicker T (2022). Social justice and the judicial interpretation of international equal protection law. Leiden Journal of International Law 35, 221-244. https://doi.org/10.1017/S0922156522000048 